\title{
STRATEGI PENGEMBANGAN USAHA TERNAK KAMBING POTONG ABU AQIQAH DI KECAMATAN KRUENG BARONA JAYA KABUPATEN ACEH BESAR
}

\author{
(Business Development Strategy Of Abu Aqiqah Cattle Goat in Krueng Barona \\ Jaya Sub District Of Aceh Besar District )
}

\author{
Firdaus $^{1}$, Irwan A. Kadir ${ }^{1}$, T.Makmur ${ }^{1 *}$ \\ ${ }^{1}$ Program Studi Agribisnis, Fakultas Pertanian, Universitas Syiah Kuala \\ *Corresponding author:tmakmur.agric@yahoo.co.id
}

\begin{abstract}
Abstrak.. Tujuan penelitian ini ialah Mengidentifikasi faktor-faktor internal dan eksternal pada usaha ternak kambing potong. Dan Mengidentifikasi strategi alternatif yang tepat untuk mengembangkan usaha ternak kambing potong. Metode penelitian yang digunakan ialah metode studi kasus mengunakan data primer dan data sekunder.Sedangkan metode analisis yang digunakan adalah metode deskriptif dan analisis strategi pengembangan.Berdasarkan hasil strategi yang dapat dijalankan adalah strategi intensif dan intergratif .Strategi yang menjadi prioritas utama yang dapat dilakukan oleh usaha Abu Aqiqah adalah meningkatkan modal guna mengembangakan teknologi.strategi tersebut merupakan strategi yang palik baik menurut penilaian STAS tertinggi 6,67. Meningkatkan modal usaha merupakan hal yang sangat penting untuk diperhatikan dalam mengembangkan usaha karena adanya proses yang dapat memudahkan usaha serta memudahkan dalam pemasaran . Dengan meningkatkan modal juga akan mendukung strategi-strategi yang lain seperti peningkatkan SDM tenaga kerja dalam hal penggunaan teknologi baru ,meningkatkan kapasitas pemasaran ternak . Semua strategi saling berkaitan dan dapat mendorong dalam upaya pengembangan usaha ternak kambing Abu Aqiqah kedepannya.
\end{abstract}

Kata kunci :Strategi, Pengembangan, Faktor Internal, Faktor Eksternal,Ternak Kambing.

Abstract. The purpose of this study is to identify internal and external factors in beef goat business. And Identifying appropriate alternative strategies for developing beef goat farming. The research method used is the case study method using primary data and secondary data. While the analytical method used is descriptive method and development analysis. Based on the results of the study strategy that can be implemented is an intensive and integrated strategy. The strategy that becomes the main priority that can be carried out by Abu Aqiqah's efforts is to increase capital to develop technology. The strategy is a good strategy according to the highest STAS assessment of 6.67. Increasing business capital is a very important thing to consider in developing a business because there are processes that can facilitate the business and facilitate marketing. Increasing capital will also support other strategies such as increasing the human resources of the workforce in terms of using new technologies, increasing the marketing capacity of livestock. All strategies are interrelated and can encourage future efforts to develop the business of the Abu Aqiqah goat.

Keywords: Strategy, Development, Internal Factors, External Factors, Goat Livestock 


\section{PENDAHULUAN}

Kambing merupakan hewan ternak kecil yang memiliki banyak kegunaan dan manfaat, disamping dapat menghasilkan daging untuk memenuhi kebutuhan protein hewani bagi masyarakat, maka produk lainnya juga bias dimanfaatkan sesuai dengan komoditas yang dihasilkan oleh ternak tersebut. Kambing Etawa merupakan jenis kambing unggul yang sangat potensial dipelihara sebagai kambing perah maupun kambing potong (Sarwono, 2002). Namun akibat kurangnya pengalaman serta pemahaman peternak kambing etawa tentang cara memerah susu kambing serta nilai tambah dari kambing etawa itu sendiri membuat peternak hanya memproduksi dagingnya saja, karena hal tersebut maka dibutuhkan suatu strategi pengembangan usaha ternak kambing dalam peningkatan pemahaman para petani tentang nilai tambah produk susu .

Menurut (Sirait, 2009), peternak kambing dihadapkan dengan berbagai permasalahan internal dan eksternal usaha ternaknya. Ketidakmampuan dalam mengelola sumberdaya yang tidak teroptimalkan merupakan permasalahan internal dalam usaha ternak kambing. Disamping permasalahan internal, peternak dihadapkan pada situasi lingkungan eksternal yang senantiasa berubah.sehingga menghambat perkembangan usaha peternakan kambing.

Usaha peternakan kambing pada Abu Aqiqah merupakan salah satu usaha yang menekuni bidang pengemukan bakal kambing potong. Kambing yang diternak di sini bervariasi jenisnya yang bertujuan mendapatkan variasi harga yang ditawar. Dalam pengembangan usaha ternak kambing bukan tanpa masalah. Fenomenal yang yang terjadi secara umum adalah disamping prospeknya yang baik tetapi memerlukan biaya yang tinggi untuk biaya produksi dan pembelian bakal kambing untuk diternak. Selain modal untuk mengembangkan usaha adanya faktor yang menjadi ancaman tersendiri bagi peternakan Abu Aqiqah yaitu perubahan lahan pertanian menjadi perumahan dan lainnya.

Managemen strategi adalah serangkaian keputusan dan tindakan manajerial usaha dalam jangka panjang. Termasuk di dalamnya pengamatan lingkungan (eksternal maupun internal), perumusan strategi (perencanaan jangka panjang), implementasi strategi, evaluasi, serta pengendalian. Bidang ilmu managemen strategi menekankan pada pengamatan evaluasi peluang dan ancaman lingkungan dengan melibatkan kekuatan dan kelemahan usaha (Setiawan, 2011).

Dalam menjalankan segala usaha diharuskan adanya manajemen yang baik agar suatu usaha mempunyai perencanaan kedepannya dalam mengembangkan usahanya. Namun pada usaha peternak Abu Aqiqah belum melakukan manajemen yang baik. Belum adanya pendataan kambing secara benar serta pengaturan arus kas yang baik. Serta ancaman lain adalah belum adanya penerapan teknologi pemasaran yang berkembang saat ini.

Berdasarkan uraian diatas maka perlu dilakukanlah penelitian yang berjudul Strategi Pengembangan Usaha Ternak Kambing Potong Abu Aqiqah di Kecamatan Krueng Barona Jaya. Adapun tujuan penelitian ini ialah Mengidentifikasi faktor-faktor internal dan eksternal pada usaha ternak kambing potong. Dan Mengidentifikasi strategi alternatif yang tepat untuk mengembangkan usaha ternak kambing potong.

\section{Waktu dan Tempat Penelitian}

\section{METODE PENELITIAN}

Penelitian ini akan dilakukan pada usaha ternak kambing potong Abu aqiqah di Desa Lamreung Kecamatan Krueng Barona Jaya. Pengambilan lokasi penelitian dilakukan secara sengaja (purposive) dengan pertimbangan hanya usaha Abu aqiqah yang telah menyediakan kambing untuk aqiqah langsung masak di Kecamatan Krueng Barona Jaya. Pertimbangan 
lainnya adalah usaha abu aqiqah yang telah berdiri pada tahun 2005 masih terdapat kendala dalam pengembangan usaha ternak kambing potong. Adapun waktu penelitian ini dilakukan pada tanggal 20 Oktober 2018.

\section{Objek dan Ruang Lingkup Penelitian}

Objek penelitian ini adalah pada usaha ternak kambing potong. Ruang lingkup penelitian terbatas pada faktor lingkungan internal dan ekstrenal serta strategi pengembangan usaha kambing potong Abu aqiqah.

\section{Populasi dan Sampel}

Populasi dalam penelitian ini sebanyak 5 orang yang terdiri dari pemilik dan pekerja pada usaha ternak kambing potong Abu Aqiqah Kecamatan Krueng Barona Jaya.Adapun penentuan sampel dengan metode sensus ( Supranto, 1993). Yaitu pengambilan semua jumlah populasi sebanyak 5 orang

\section{Metode Pengumpulan Data}

Metode penelitian yang digunakan ialah metode studi kasus menggunakan data primer dan data sekunder.

\section{Metode Analisis}

Sedangkan metode analisis yang digunakan adalah metode deskriptif dan analisis strategi pengembangan.

\section{Analisis Deskriptif}

Analisis deskriptif digunakan untuk memperoleh gambaran secara sistematis dan akurat mengenai fakta-fakta permasalahan yang akan diteliti serta mengkaji strategi pengembangan yang telah dilakukan oleh peternak kambing Abu Aqiqah di Kecamatan Krueng Barona Jaya.

\section{HASIL DAN PEMBAHASAN}

\section{A. Identifikasi Faktor Lingkungan Usaha Ternak Kambing Potong Abu Aqiqah}

\section{Identifikasi Faktor Internal}

Berdasarkan hasil analisis lingkungan internal, maka diperoleh beberapa faktor kekuatan dan kelemahan yang berpengaruh terhadap pengembangan usaha ternak kambing potong Abu Aqiqah di Desa lamreung.

1) Pekerja yang berpengalaman

Pekerja yang berpengalaman merupakan kekuatan dari usaha ternak kambing potong Abu Aqiqah. Karena dengan tingkat pengalaman yang lama dalam beternak yang akan mempengaruhi usaha ternak kambing potong yang akan di produksi. Semakin lama pengalaman para pekerja dalam melakukan usahanya maka para peternak sudah memahami segala kendala serta cara mengatasinya .

2) Pemasaran ternak yang mudah

Pemasaran ternak kambing yang mudah menjadi salah satu kekuatan bagi usaha Abu Aqiqah karena para pembeli langsung ketempat usaha sehingga memudah peternak . dan kemudahan dalam pemasaran terjadi karena usaha ternak abu aqiqah ini telah lama berdiri dan telah banyak pelanggan yang menginfokan tentang usaha ini serta kembali untuk membeli kambing pada tahun- tahun selanjutnya.

3) Lokasi yang strategis 
Lokasi usaha salah satu pendukung sekaligus menjadi kekuatan untuk pemasaran ternak . lokasi usaha ternak kambing Abu Aqiqah berada dekat dengan pasar hewan $\pm 1 \mathrm{~km}$ serta dekat dengan jalan penghubung antar Kecamatan krueng Barona Jaya dengan Kecamatan Syiah Kuala

4) Harga yang bervariasi

Harga yang bervariasi merupakan bagian untuk kelancaran usaha dalam memasarkan ternaknya. Dengan harga yang bervariasi akan memudah kan pembeli untuk membeli kambing potong. Harga yang bervariasi ini karena perbedaan jenis kambing, bobot serta umur kambing tersebut. Harga yang di tawarkan berkisaran 2 juta hingga 5 juta.

5) Ketersediaan pakan yang cukup

Ketersediaan pakan yang cukupsangat mendukung peternakan kambing Abu Aqiqah karena dapat memudahkan bapak Nasrudin dalam mencari pakan hijau maupun mengembala kambing di sekitar peternakannya saja. Dengan Ketersediaan pakan yang cukupini banyak tumbuhan pendukung lain untuk pakan ternak sehingga nutrisi untuk kambing terpenuhi dan membuat bobot kambing bertambah.

Sedangkan faktor kelemahan yang dimiliki usaha ternak kambing potong Abu

Aqiqah adalah sebagai berikut :

1) Penyakit.

Penyakit suatu kelemahan yang dapat membahayakan kodisi ternak kambing kata pak Nasrudin jika salah dalam penanganan kambing yang terserang penyakit dapat mengakibatkan kambing mati . Penyakit yang sering terjadi yaitu diare, dan perut kembung. Dalam penanganan penyakit bapak Nasrudin masih menggunakan obat tradisional . apabila kambing tidak sembuh dalam 3 hari maka pak Nasrudin segera menjual kambing tersebut dengan harga murah ke rumah" makan .

2) Kelangkaan Bibit.

Kelangkaan bibit merupakan suatu kelemahan yang terjadi akibat banyaknya rumah makan yang membeli indukan betina yang masih produktif. Dengan terjadinya kelangkaan bibit terhabatnya pemasokan bibit baru untuk di gemukkan serta dapat mempengaruhi produksi selajutnya .

3) Kurangnya modal.

Modal merupakan salah satu faktor pendukung untuk mengembangkan usaha namun pak Nasrudin memiliki keterbatas sehingga modal menjadi salah satu faktor kelemahan untuk pengembangan usaha ternak kambingnya. Pak Nasrudin tidak pernah meminjam uang dari bank karena laporan arus kas yang tidak tercatat serta bapak Nasrruddin tidak ingin adanya riba saat peminjaman uang dari bank.

4) Alat-alat produksi yang tradisonal.

Alat-alat Produksi yang digunakan bapak Nasrudin masih tergolong tradisional . sebenarnya alat-alat produksi dapat membantu peternak untuk memudahkan pekerjaan peternak seperti pak Nasrudin yang mana beliau tidak ada tenaga kerja tambahan selain keluarganya dan 1 orang pemotong rumput yang diupah, adapun alat-alat produksi yang masih tradisional ialah sabit, pemberian minum pakai ember .

5) Manajemen usaha yang kurang baik.

Manajemen usaha dapat mempengaruhi suatu usaha untuk kedepannya, manajemen usaha yang kurang baik inilah yang menjadi salah satu faktor usaha bapak Nasrudin ini sampai sekarang belum berkembang. Tidak ada nya manajemen organisasi, pendataan ternak serta pencatatan arus kas yang baik. 


\section{Identifikasi Faktor Eksternal}

Berdasarkan hasil analisis lingkungan eksternal yang diperoleh dari usaha ternak kambing potong Abu Aqiqah, maka diperoleh peluang dan ancaman yang berpengaruh terhadap pengembangan usaha ternak kambing potong. Faktor peluang usaha adalah sebagai berikut :

1) Peningkatan permintaan .

Salah satu peluang usaha ternak Abu Aqiqah adalah adanya peningkatan permintaan kambing potong. Permintaan yang meningkat ini terjadi akibat dari lokasi yang strategis, pertumbuhan penduduk dan banyaknya rumah makan kuah kambing yang baru. Tingkat pertumbuhan penduduk di wilayah Banda Aceh sangat mempengaruhi tingkat permintaan serta tingkat kelahiran sehingga bapak Nasrudin dapat menyediakan kambing' untuk acara aqiqah .

2) Hubungan dengan konsumen yang baik.

Hubungan dengan konsumen yang baik yang dilakukan bapak Nasrudin sangat baik karena beliau yakin bahwa salah satu faktor berkembangnya usaha adalah memberikan pelayan konsumen dengan baik. Dan pak Nasrudin selalu menyimpan nomor konsumennya untuk menawarkan kembali kambingnya pada waktu mendekati Qurban. Dengan adanya nomor yang disimpan oleh napak Nasrudin ini merupakan salah satu cara membangn komunikasi dengan konsumennya.

3) Hubungan dengan Pemasok yang baik.

Ketersediaan bibit kambing bakal pengemukan berkaitan langsung dengan adanya hubungan dengan pemasok. Bapak Nasrudin menerima kemudahan dari pemasok kambing sebab lamanya kerja sama yang telah dijalankan atas dasar kepercayaan .

4) Mayoritas masyarakat Aceh beragama islam.

Mayoritas masyarakat Aceh beragama islam adalah salah satu peluang bagi usaha ternak Abu Aqiqah dimana setiap kelahiran masyoritas masyarakat Aceh membuat serangkaian acara dan kuah kambing merupakan salah satu menu yang sering disajikan . selain itu ada satu momen lain bagi umat muslim yaitu saat qurban, dimana kambing merupakan salah satu hewan qurban yang dibeli oleh kaum muslim padat saat qurban kambing telah dipesan jauh-jauh hari sehingga bapak Nasrudin memasok ternak kambingnya sampai 70 ekor lebih.

5) Kondisi lingkungan yang kondusif dan aman

Lingkungan yang kondusif dan aman menjadi salah satu peluang bagi usaha ternak kambing . dengan lingkungan yang kondusif ini kambing terhindar dari stress. Serta aman dari ancama binatang buas seperti anjing . lingkungan yang kondusif dan aman ini sangat membantu bapak Nasrudin untuk mengembala kambing nya di pagi hingga sore hari nya

Sedangkan faktor ancaman yang dimiliki usaha ternak kambing potong Abu Aqiqah ialah sebagai berikut :

1) Munculnya pesaing baru.

Pesaing merupakan salah satu faktor yang dapat menjadi ancama suatu usaha, peternakan kambing tentunya mempunyai banyak pesaing, di kawasan Krueng barona jaya menjadikan ternak kambing sebagai usaha sambilan saja. Namun di tahun 2019 sudah ada pesaing baru di kawasan Krueng barona jaya yaitu usaha limo farm, ini menjadi suatu ancama tersendiri bagi usaha ternak Abu Aqiqah sehingga diharuskan adanya inovasi baru dalam pemasaran dan lainnya agar usaha ternak Abu Aqiqah dapat bertahan dan berkembang. 
2) Perubahan cuaca.

Perubahan cuaca salah satu faktor yang dapat mempengaruhi usaha ternak kambing sehingga menjadi suatu ancama bagi peternak serta kambing itu sendiri walaupun banyak kambing yang telah tahan terhadap cuaca di wilayah Indonesia, pada saat hujan kebersihan kadang sangat mempengaruhi kesehatan kambing serta pakan yang di beri harus jangan sampai mengandung banyak air karena dapat membuat kambing mencret.

3) Tidak ada dukungan pemerintah.

Pemerintah seharusnya menjadi salah satu faktor pendukung untuk keberhasilan usaha ternak kambing ini karena dapat menjadikan Aceh berkecukupan kambing di daerah. Namun menurut diskusi saya bersama bapak Nasrudin terjadinya kesenjangan dimana peran pemerintah malah bisa menjatuhkan usaha para peternak kambing, karena ketidak tepat sasarannya pemerintah dalam memberi bantuan. Kata pak Nasrudin penah ada kawan beliau yang berpropesi bukan peternak kambing malah menerima bantuan kambing untuk di ternak.

4) Belum adanya penyuluh

Belum adanya penyuluh merupakan merupakan salah satu faktor yang akan menjadi ancaman bagi peternakan bapak Nasrudin kedepannya. Karena peran penyuluh pertanian sangat dibutuhkan oleh peternak kambing seperti bapak Nasrudin untuk mengembangakan usahanya. Karena belum adanya petugas penyuluh para peternak akan susah mengetahui info seputar perkembangan dalam mejalankan usaha ternak kambing seperti pengolahan pakan fermentasi, pemanfaatan teknologi pemasaran dan persaingan ternak dari luar Aceh.

5) Perkembangan teknologi

Perkembangan teknologi sekarang sudah sangat maju sehingga dapat menjadi salah satu faktor ancaman bagi usaha peternakan bapak Nasrudin. Karena teknologi sekarang menjadi salah satu alat yang baik dalam meningkatkan nutrisi pada pakan serta dapat memudahkan peternak dalam penyiapan serta menyimpan pakannya dalam waktu yang lama .

1. Analisis Matriks IFE (Internal Factor Evaluation).

Berikut adalah hasil analisis matriks IFE, yang merupakan faktor-faktor Kekuatan dan kelemahan yang terdiri dari nilai bobot dan peringkat serta skor seperti pada tabel berikut : Tabel 1. Matrik evaluasi faktor internal

\begin{tabular}{lllll}
\hline No & Faktor Internal & Bobot & Peringkat & Skor \\
\hline 1 & Pekerja yang berpengalaman & 0,11 & 3 & 0,33 \\
2 & Pemasaran ternak yang mudah & 0,115 & 4 & 0,46 \\
3 & Lokasi yang strategis & 0,11 & 3 & 0,33 \\
4 & Harga yang bervariasi & 0,12 & 4 & 0,48 \\
5 & Ketersediaan pakan yang cukup & 0,105 & 3 & 0,315 \\
\hline \multicolumn{2}{l}{ Subtotal A } & & & 1,915 \\
\hline 6 & Penyakit & 0,08 & 2 & 0,16 \\
7 & Kelangkaan Bibit & 0,09 & 2 & 0,18 \\
8 & Kurangnya modal & 0,095 & 3 & 0,285 \\
9 & Alat-alat produksi yang tradisonal & 0,08 & 1 & 0,08 \\
10 & Manajemen usaha yang kurang baik & 0,095 & 2 & 0,19 \\
\hline & Subtotal B & & & 0,895 \\
\hline & Total Subtotal A dan subtotal B & &
\end{tabular}

Sumber : Data Primer (2019). 
Berdasarkan hasil perhitungan pada tabel 1, hal ini menunjukkan bahwa usaha ternak kambing Abu Aqiqah dapat memanfaatkan kekuatan yang dimiliki untuk mengurangi kelemahan yang ada ditunjukkan pada subtotal skor kekuatan lebih besar yaitu 1,915 sedangkan subtotal kelemahan lebih kecil sebesar 0,895. Adapun total nilai dari analisis matriks IFE yang merupakan faktor kekuatan dan kelemahan sebesar 2,81.

\section{Analisis Matriks EFE (Internal Factor Evaluation).}

Berikut adalah hasil analisis matriks EFE, yang merupakan faktor-faktor peluang dan ancaman yang terdiri dari nilai bobot dan peringkat serta skor seperti pada tabel berikut : Tabel 2. Matrik evaluasi faktor eksternal

\begin{tabular}{lllll}
\hline No & Faktor Eksternal & Bobot & Peringkat & Skor \\
\hline 1 & Meningkatnya Permintaan & 0,12 & 4 & 0,48 \\
2 & Hubungan dengan konsumen yang baik & 0,105 & 3 & 0,315 \\
3 & Hubungan dengan pemasok yang baik & 0,11 & 4 & 0,44 \\
4 & Mayoritas masyarakat Aceh beragama islam & 0,105 & 3 & 0,315 \\
5 & Kondisi lingkungan yang kondusif dan aman & 0,115 & 4 & 0,46 \\
\hline & Subtotal A & & & 2,01 \\
\hline 6 & Muclnya pesaing baru & 0,08 & 2 & 0,17 \\
7 & Perubahan cuaca & 0,095 & 2 & 0,19 \\
8 & Tidak adanya dukungan pemerintah & 0,09 & 3 & 0,27 \\
9 & Belum adanyanya petugas penyuluh & 0,095 & 2 & 0,19 \\
10 & Perkembangan teknologi & 0,08 & 3 & 0,24 \\
\hline & Subtotal B & & & 1,06 \\
\hline & Total Subtotal A dan subtotal B & & & 3,07 \\
\hline
\end{tabular}

Sumber : Data Primer (2019)

Berdasarkan hasil perhitungan pada tabel 6, hal ini menunjukkan bahwa usaha ternak kambing Abu Aqiqah dapat memanfaatkan peluang yang dimiliki untuk menghadapi ancaman yang ada ditunjukkan pada subtotal skor peluang lebih besar yaitu 2,01 sedangkan subtotal ancaman lebih kecil sebesar 1,06. Adapun total nilai dari analisis matriks EFE yang merupakan faktor kekuatan dan kelemahan sebesar 3,07.

\section{Tahap Pencocokan}

Tahap pencocokan merupakan tahapan kedua dalam perumusan strategi yang bertujuan untuk memadukan faktor internal yaitu kekuatan dan kelemahan dengan faktor eksternal yaitu peluang dan ancaman yang terdapat pada usah ternak Abu Aqiqah. Alat yang digunakan adalah matirks SWOT.

\section{Analisis matriks IE}

Matrikks IE digunakan untuk melihat posisi usaha pada pertumbuhan dan persaingan suatu usaha yang dihadapi. Matriks IE menempakatkan usaha dalam dapat di lihat pada Tabel 3. 
Tabel 3. Matrik analisis IE

\begin{tabular}{ccccc}
\hline & & \multicolumn{3}{c}{ Total nilai IFE yang diberibobot } \\
\cline { 3 - 5 } & & Kuat & Rata-rata & Lemah \\
& $3,0-4,0$ & $2,0-2,99$ & $1,0-1,99$ \\
\hline & $\begin{array}{c}\text { Tinggi } \\
3,0-4,0\end{array}$ & I & II & III \\
\cline { 2 - 5 } Total nilai & Sedang & IV & V & VI \\
EFE yang & $2,0-2,99$ & V & & IX \\
diberibobot & Rendah & VII & VIII & \\
\cline { 2 - 5 } & $1,0-1,99$ & & &
\end{tabular}

Sumber : Data Primer (2019)

Adapun hasil analisis diatas yaitu total skor IFE yang dimiliki usaha ternak kambing Abu Aqiqah ialah 2,81 dan total skor EFE ialah 3,07. Sehingga titik koordinal yang ditunjukkan diatas ialah 2,81:3,07.Total dari matriks EFE mengambarkan respon yang diberikan lingkungan eksternal lebih kuat dalam memanfaatkan peluang dan mengatasi ancaman. Dari hasil analisis diatas juga mengambarkan bahwa kondisi usaha Abu Aqiqah berada pada sel II, yaitu kondisi tumbuh dan berkembang. Strategi yang dapat dijalankan adalah strategi intensif dan intergratif .

\section{Matriks Analisis SWOT}

Adapun hasil analisis matriks SWOT ialah sebagai tabel 4 berikut :

Tabel 4. Matrik analisis SWOT

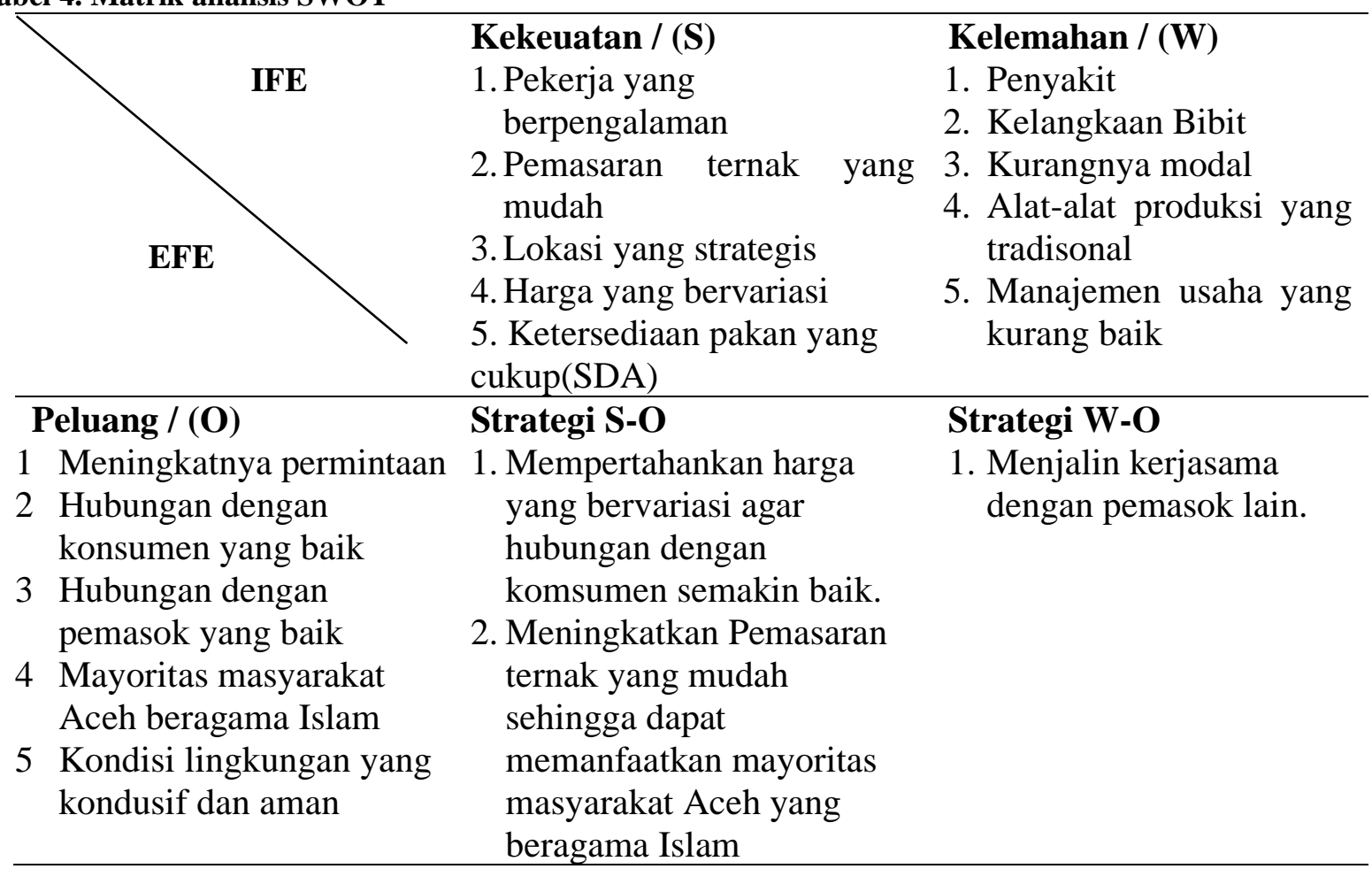




\section{Ancaman / (T)}

1. Munculnya pesaing baru

2. Perubahan cuaca

3. Tidak ada dukungan pemerintah

4. Alih fungsi lahan

5. Perkembangan teknologi

\section{Strategi S-T}

1. Meningkatkat SDM tenaga

kerja yang berpengalaman

dalam hal pemahaman

internet/teknologi

\section{Strategi W-T}

1. Meningkatkan modal

usaha guna

mengembangkan

teknologi.

\section{Sumber : Data Primer (2019)}

Alternatif strategi dapat dirumuskan berdasarkan model analisi SWOT. Strategi yang dapat dilakukan yaitu : strategi SO, strategi ST, strategi WO dan strategi WT. Maka alternatif strategi yang dapat dilakukan adalah sebagai berikut :

a. Strategi S-O ( Strength-Opportunities).

Strategi SO adalah strategi yang menggunakan kekuatan faktor internal serta memanfaatkan peluang faktor ekternal yang dapat diterapkan oleh usaha ternak Abu Aqiqah. 1. Mempertahankan harga yang bervariasi agar hubungan dengan komsumen semakin baik.

Usaha ternak Abu Aqiqah memiliki variasi harga yang harus dipertahankan karena variasi harga merupakan salah satu kekuatan yang dapat digunakan serta memanfaatkan peluang hubungan dengan konsumen yang baik . dengan variasi harga seperti ini dapat mempermudah konsumen dalam memilih ternak kambing yang ingin dibeli . dengan lancarnya pemasaran yang dijalankan hubungan dengan konsumen akan meningkat lebih baik sehingga konsumen dapat membeli kambing yang di ternak oleh bapak Nasrudin pada acara-acara kedepannya. Variasi harga ini terjadi karena adanya variasi kambing yang diternakan oleh bapak Nasrudin. Kambing yang diternak oleh bapak Nasrudin ialah kambing kacang dan kambing PE.

2. Meningkatkan Pemasaran ternak yang mudah sehingga dapat memanfaatkan mayoritas masyarakat Aceh yang beragama Islam . (S2)

Dengan menggunakan kekuatan pemasaran yang mudah karena adanya peluang berupa mayoritas masyarakat Aceh beragama islam . Dengan demikian peternakan Abu Aqiqah dapat mengembangkan sistem pemasarannya dengan cara meningkatkan sarana promosi melalui media sosial seperti facebook, WA, dan instragram . tentunya dengan mayoritas masyarakat Aceh yang beragama islam adanya momen-momen yang memerlukan kambing seperti acara aqiqah anak yang baru lahir ataupun pada hari raya idul adha.

b. Strategi S-T(strenght-threats).

strategi S-T adalah strategi yang menggunakan kekuatan untuk menghadapi ancaman .adapun strategi yang dapat diterapkan pada usaha ternak kambing Abu Aqiqah yaitu :

1. Meningkatkat SDM tenaga kerja yang berpengalaman dalam hal pemahaman internet (S3).

Kekuatan SDM tenaga kerja yang berpengalam dalam hal beternak harus dipadukan dengan perkembangan zaman dimana setiap usaha harus memulai untuk meningkatkan SDM dalam hal internet . karena perkembangan dunia internet dapat menjadi suatu media dalam meningkatkan pejualan serta memudahkan dalam hal promosi.

c. Strategi W-O( weakness-opportunities).

Strategi WO adalah strategi untuk mengatasi kelemahan internal dengan meanfaatkan peluang eksternal yang ada. Adapun strategi yang digunakan usaha ternak Abu Aqiqah yaitu : 
1. Menjalin kerja sama dengan pemasok lain (S4).

Menjalin kerjasama dengan pemasok lain adalah satu upaya mengatasi kelangkaan bibit pada satu pemasok . sehingga dengan adanya kerjasama dengan pemasok lain dapat memastikan ketersedian bibit yang siap diternak sehingga alur produksinya tidak terhenti. Dalam menjalin kerja sama dengan pemasok bapak Nasrudin juga harus membuat perjanjian /kontrak agar dapat menghindari usaha dari hal-hal yang tidak diinginkan serta dapat merugikan usaha.

Perjanjian usaha Abu Aqiqah dengan pemasok lain bertujuan untuk dapat memperoleh ternak yang sehat dan tetap mendapatkan bibit ternak pada waktu tertentu dalam jumlah yang sesuai dengan permintaan. Strategi ini dapat mengurangi kelemahan usaha ternak kambing Abu Aqiqah seperti kelangkaan bibit serta terhindarnya mendapatkan ternak yang terserang penyakit . selain itu strategi ini dapat memberikan peluang baru untuk usaha Abu Aqiqah dalam mengembangankan usahanya dalam skala produksinya.

d. Strategi W-T ( weakness-opportunitiess).

Strategi WT adalah strategi yuntuk mengurangi kelemahan internal serta menghindari ancaman eksternal yang ada. Adapun strategi yang digunakan pada usaha Abu Aqiqah yaitu :

Modal merupakan salah satu faktor Produksi yang penting dalam suatu usaha sehingga dapat memudahkan setiap peternak dalam mengembangkan usahanya. Harus adanya upaya dari bapak Nasrudin untuk meninkatkan modal dalam usahanya guna meningkatkan penggunaan teknologi baru . Adapun cara-cara yang harus digunakan adalah menjalin kerja sama dengan investor ataupun mencari bantuan pemerintah . Dengan adanya kerjasama dengan investor ataupun bantuan dari investor bapak Nasrudin dapat membeli alat-alat untuk memproduksi pakan seperti mesin pemotong rumput, mesin pencacah rumput . dan alat-alat fermentasi rumput untuk menjadikannya pakan yang beruntrisi serta tahan lama.

Selain dari investor ataupun bantuan pemerintah bapak Nasrudin juga dapat meminjam dana dari koperasi ataupun intansi terkait. Sistem yaang terdapat pada koperasi ataupun intansi terkait dengan peternakan menjadi salah satu pilihan untuk mendapatkan modal tambahan . Dengan adanya modal yang didapatkan dapat membantu pengembangan usaha ternak Abu Aqiqah baik dalam pembelian alat-alat pembuatan pakan juga dapat digunakan untuk menambah kandang serta karyawan untuk bekerja.

Matriks QSPM (Quantitative Strategic Planning Matrix).

Matriks QSPM (Quantitative Strategic Planning Matrix) ialah sebagai alat dalam proses pengambilan keputusan dari analisis strategi usaha. Matriks QSPM dibuat berdasarkan faktor-faktor yang mempengaruhi baik internal yang kemudian dilakukan pencocokan melalui matriks SWOT.Martriks QSPM terdiri dari nilai AS (attraktiveness score) atau daya tarik dan nilai TAS (total attractiveness score) total nilai daya tarik. Nilai AS juga diperoleh dari pengisian kuisoner yang ditunjukan kepada responden yaitu bapak Nasrudin selaku pemilik usaha ternak kambing Abu Aqiqah. Responden sangat berpengaruh sangat besar dalam merumuskan strategi yang tepat bagi usaha. Nilai tas diperoleh dari hasil perkalian antara bobot dari setiap faktor dalam alternatif yang dikalikan dengan nilai AS. 
Tabel 5. Matrik Analisis QSPM

\begin{tabular}{lcc}
\hline \multicolumn{1}{c}{ Strategi } & TAS & Prioritas \\
\hline $\begin{array}{l}\text { Mempertahankan harga yang bervariasi agar hubungan } \\
\text { dengan komsumen semakin baik. }\end{array}$ & 6,455 & 2 \\
$\begin{array}{l}\text { Meningkatkan Pemasaran ternak yang mudah sehingga dapat } \\
\text { memanfaatkan mayoritas masyarakat Aceh yang beragama }\end{array}$ & 6,355 & 3 \\
$\begin{array}{l}\text { Islam. } \\
\text { Meningkatkat SDM tenaga kerja yang berpengalaman dalam }\end{array}$ & 5,565 & 4 \\
$\begin{array}{l}\text { hal pemahaman internet/teknologi. } \\
\text { Menjalin kerjasama dengan pemasok lain. }\end{array}$ & 4,845 & 5 \\
Meningkatkan modal usaha guna mengembangkan teknologi. & 6,67 & 1 \\
\hline
\end{tabular}

Sumber : Data Primer (2019)

Berdasarkan hasil dari matriks QSPM, maka strategi yang menjadi prioritas utama yang dapat dilakukan oleh usaha Abu Aqiqah adalah meningkatkan modal guna mengembangakan teknologi.strategi tersebut merupakan strategi yang palik baik menurut penilaian STAS tertinggi 6,67. Meningkatkan modal usaha merupakan hal yang sangat penting untuk diperhatikan dalam mengembangkan usaha karena adanya proses yang dapat memudahkan usaha serta memudahkan dalam pemasaran . Dengan meningkatkan modal juga akan mendukung strategi-strategi yang lain seperti peningkatkan SDM tenaga kerja dalam hal penggunaan teknologi baru ,meningkatkan kapasitas pemasaran ternak. Semua strategi saling berkaitan dan dapat mendorong dalam upaya pengembangan usaha ternak kambing Abu Aqiqah kedepannya.

\section{Kesimpulan}

\section{KESIMPULAN DAN SARAN}

Adapun kesimpulan yang dapat diambil dari penilitian ini adalah sebagai berikut

1. Faktor internal yang dapat mempengaruhi usaha Abu Aqiqah ialah kekuatan terdiri dari pekerja yang berpengalaman, pemasaran ternak yang mudah, lokasi yang strategis, harga yang bervariasi, ketersediaan pakan yang cukup. Dan kelemahan terdiri dari penyakit, kelangkaan bibit, kurangnya modal, alat-alat produksi yang tradisional, manajemen usaha yang kurang baik. Sedangkan faktor eksternal yang dapat mempengaruhi adalah faktor peluang meningkatnya permintaan, hubungan dengan konsumen yang baik, hubungan dengan pemasok yang baik, mayoritas masyarakat Aceh beragama islam, kondisi lingkungan yang kondusif dan aman. Dan ancaman munculnya pesaing baru, perubahan cuaca tidak ada dukungan pemerintah ,belum adanya petugas penyuluh, dan perkembangan teknologi.

2. Strategi usaha Abu Aqiqah berdasarkan analisis SWOT berada pada kuadran II yang berarti startegi yang dapat dijalankan iyalah intensif dan intergratif. Dan ada 5 strategi yang menjadi prioritas untuk mengembangkan usaha Abu Aqiqah yaitu :

Mempertahankan harga yang bervariasi agar hubungan dengan komsumen semakin baik, Meningkatkan Pemasaran ternak yang mudah sehingga dapat memanfaatkan mayoritas masyarakat Aceh yang beragama Islam, Meningkatkat SDM tenaga kerja yang berpengalaman dalam hal pemahaman internet/teknologi. Menjalin kerjasama dengan pemasok lain, Dan Meningkatkan modal usaha guna mengembangkan teknologi. 


\section{Saran}

Adapun saran untuk usaha ternak kambing Abu Aqiqah adalah :Sebaiknya melakukan penambahan modal usaha dalam mengembangkan usaha ternak kambing kedepannya .Sehingga segala pekerjaan dapat lebih efisien dan dapat meningkatkan jumlah penjualan ternak kambing. Lakukan pemasaran menggunakan media sosial yang saat ini sedang berkembang.

\section{DAFTAR PUSTAKA}

Aswara, DAW dan Sri H.2014. Perencanaan Strategi bisnis UKM Produk Berbahan Limbah Kayu Menggunakan Metode Quantitave Strategy Planning Matrix (QSPM) Studi Kasus : Ud.Murdoso. Jurnal Universitas Diponegoro No. 3 Vol.4.

David FR. 2006. Manajemen Strategis. Sindoro A, penerjemah; Jakarta: PT Indeks. Terjemahan dari: Concepts of Strategic Management.

David FR. 2011. Strategic Management. Edisi10. Jakarta: Salemba Empat.

Haryana, S. 2013. Strategi Pengembangan Industri Rumah Tangga Kerajinan Rotan di Desa

Kueh Kecamatan Lhoknga kabupaten Aceh Besar. Skripsi. Jurusan Sosial Ekonomi Pertanian, Fakultas Pertanian Universitas Syiah Kuala, Banda Aceh.

Hotmarida, S. 2017. Strategi Pengembangan Ternak Sapi Potong Berorientasi Agribisnis di Kecamatan Kuta Baro kabupaten Aceh Besar. Skripsi. Program Studi Agribisnis, Fakultas Pertanian Universitas Syiah Kuala, Banda Aceh.

Hunger, J. David dan Wheelen. 1998. Manajemen Strategi. Andi. Yokyakarta.

Kinnear TC, Taylor IR. 1991. Marketing Research an Applied Approach. McGraw-Hill International Edition.

Mulyono S. 2003. Teknik Pembibibitan Kambing Unggul dan Domba, Jakarta : Penebar Swadaya.

Pearce JA. Robinson B. 1997. Manajemen Strategi :Formulasi, Implementasi, dan Pengendalian. Jakarta: Binarupa Aksara.

Rahmawaty, S. 2016. Analisis Strategi Pengembangan Usaha Peternakan Kambing PT. Alam Desa Tapos di Kecamatan Tenjolaya kabupaten Bogor. Departemen Agribisnis, Fakaultas Ekonomi dan Manajemen Insttitusi Pertanian Bogor, Bogor.

Rangkuti F. 2003. Analisis SWOT Teknik Membedah Kasus Bisnis: berorientasi konsep perencanaan strategis untuk menghadapi abad 21. Jakarta: PT Gramedia Pustaka Utama.

Rukmana R. 2015. Wirausaha Ternak Kambing PE Secara Intensif. Lily Publisher. Yokyakarta.

Sarwono B. 2002. Beternak Kambing Unggul. Jakarta: Penebar Swadaya.

Sasongko TH. 2006. Analisis Strategi Pengembangan Usaha Peternakan Kambing dan Domba pada MT Farm, Ciampea Bogor [skripsi]. Bogor: Fakultas Pertanian, Institut Pertanian Bogor.

Supranto, 1993. Metode Penelitian Aplikasi dalam Pemasaran, Penerbit. PT. Gramedia Pustaka Utama, Jakarta.

Sekaran, U., 2011, Reseach Methods For Business: A Skill Building Approach $2^{\text {nd }}$ edition, Singapore; Jhon Wiley \&Sons, Inc.

Setiawan, A. 2011 .Analisis Kinerja Usaha Dodol Olimpic Garut Dengan Blanced Scorecard. Tugas Akhir Jurusan Teknik Dan Managemen Industri Sekolah Tinggi Teknologi Garut. 
Sirait, J. 2009. Strategi Pengembangan Usaha Peternakan Kambing Perah Pada PT. Caprito A. Kecamatan Cariu Kabupaten Bogor. Skripsi. Departemen Agribisnis, Fakultas Ekonomi dan Manajemen, Bogor.

Steiner GA, Miner JB. 1997. Kebijakan dan Strategi Manajemen. Jakarta: Erlangga. Umar, Husein. 1999. Riset Strategi Usaha. PT. Gramedia Pustaka Utama, Jakarta. Umar H. 2008. Strategic Management In Action. PT. Gramedia Pustaka Utama. Jakarta. Wicaksono, D. A. 2010. Analisis Strategi Rantai Pasok Udang Vaname (Studi Kasus Petani Plasma Tambak Pandu Karawang, Kabupaten Karawang, Jawa Barat) Skripsi. Fakultas Pertanian. Institut Pertanian Bogor. Bogor. 